\title{
Techniques of DNA-studies on Prehispanic Ectoparasites (Pulex sp., Pulicidae, Siphonaptera) from Animal Mummies of the Chiribaya Culture, Southern Peru
}

\author{
K Dittmar/ ${ }^{+}$, U Mamat*, M Whiting, T Goldmann*, K Reinhard**, S Guillen*** \\ Brigham Young University, Department of Zoology, Provo, Utah, USA *Research Center Borstel, Center for Medicine and \\ Biosciences, Borstel, Germany **School of Natural Resource Sciences, University of Nebraska-Lincoln, Lincoln, Nebraska, USA \\ ***Centro Mallqui, Bioanthropology Foundation, Ilo, Peru
}

During a paleoparasitological survey of several animal mummies (Cavia aperea f. porcellus and Canis familiaris) from Chiribaya Baja, an archaeological site in Southern Peru, an unexpected find was made. In the well preserved fur, large numbers of mummified fleas (Pulex simulans/irritans) that parasitized the animals during life were encountered.

Due to the relative recent event of the host mummification and the outstanding preservation of the fleas, an attempt for the retrieval of DNA was made. A DNA extraction and sequencing protocol for archaeological ectoparasitic remains has been established, taking additional studies for tissue and protein preservation into account. Tissue preservation was assessed with transmission electron microscopy and the protein preservation was tested through the racemisation ratios of aspartic acid. Regions of the $28 S$ rDNA gene were successfully amplified and sequenced. Further research perspectives are outlined.

Key words: animal mummies - ectoparasites - Pulex sp. - aDNA - Peru

Generally, arthropod remains are rarely found among archaeological material. Arthropods, like any other organic material are subjected to post mortem decay. The size and the fragility of most arthropods greatly limit the possibility of retrieval at archaeological sites (Kenward 1978a). Most records of arthropods from archaeological sites are limited to records of subfossil mites from soil samples of archaeological deposits (Kenward 1978b, Girling 1978). Traditionally those samples have been used for paleoenvironmental and paleoclimatic analyses. Occasionally, arthropods are found in coprolites, contributing to the knowledge of dietary components in historic societies (Bryant 1974, Panagiotakopulu 1999).

Several accounts of prehistoric ectoparasites are mentioned in the literature. Most records describe louse infections in prehistoric populations throughout the world. Paleoparasitological studies carried out by Ewing (1924), Panagiotakopulu et al. (1995/1997) reveal head lice infections in Egyptian mummies (Pediculus humanus capitis). Later, New World mummies were found to be infected with head, body (P. humanus humanus) and pubic lice (Phtirus pubis) (Ewing 1924, Araujo et al. 2000). Flea specimens have been found occasionally among Eskimo mummies in Greenland and the Arctic (Lynnerup, pers. commun.). Animal ectoparasites are rarely recorded, mainly because of the scarce availability and poor preservation of animal mummies. Lipoptena cervi, a hippoboscid fly of deer, has been found on the ice-man mummy from the Austro-Italian border (Gothe \& Schöl 1992).

${ }^{+}$Corresponding author. Fax: +1-801-422.0090.

E-mail: katharinad@ hotmail.com

Received 26 August 2002

Accepted 25 November 2002
All mentioned records refer to very low sample sizes. No attempt of a retrieval of DNA from these parasites has ever been made. The sample size of the Chiribaya material exceeds all previous reports, with over 1,200 single specimens of Pulex sp. In the following article we will give a description of the procedures used for the retrieval of DNA from various specimens of Pulex sp., that were found on the animal mummies of the Chiribaya Culture. These procedures can be applied to all kinds of archaeological ectoparasitic remains. Two lines of research could benefit from these studies. One is mostly of entomological interest, where results may shed light on the somewhat unclear taxonomic relationship between $P$. simulans and $P$. irritans. The second problem relates to the medical importance of the Pulex-complex as vectors of infectious agents, such as devastating diseases like plague. This material gives us the ability to track the spread of disease historically.

\section{MATERIALS AND METHODS}

Sample collection - In total 159 guinea pig mummies (Cavia apereaf. porcellus) and 17 dog mummies (Canis familiaris) have been screened. The archaeological sites are located in the Moquegua Valley, in the Southern part of Peru. The sites are dated to the Middle Horizon, at about 900 A.D. Over 1,200 fleas of the genus Pulex were recovered from the animal mummies. For the study, only specimens from dog mummies have been used. All animal mummies are stored in the Centro Mallqui, Bioanthropology Foundation, Casilla 18, Peru. All flea specimens are preserved in $100 \%$ ethanol at $-80^{\circ} \mathrm{C}$, at the Whiting Lab, Department of Zoology, BYU.

Most of the specimens seemed to be preserved in good conditions, although some fragile structures, such as legs, antennae or mouthparts were missing (Fig. 1). In addition, 


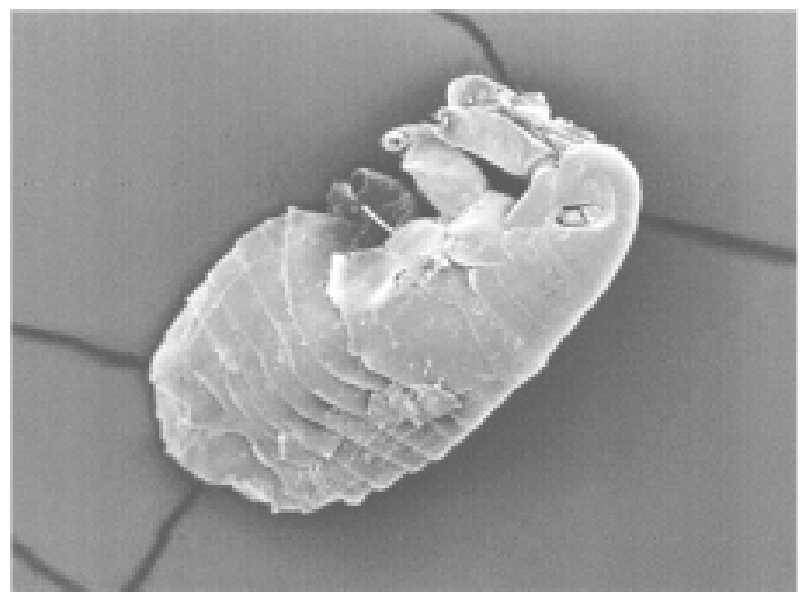

Fig. 1: scanning electron microscopy of ancient Pulex sp., $1000 \mathrm{X}$.

the key characters used for species identification (genitalia, comb structure, etc.) are well-preserved.

However, sample appearance often has little to do with the quality of molecular preservation. Therefore, in order to substantiate claims of recovery of ancient DNA, several assessments of tissue and protein preservation have been performed in addition to DNA extraction and amplification (Hofreiter et al. 2001).

Tissue preservation - Two fleas were prepared for transmission electron microscopy analysis. The following method was applied: the flea was rehydrated for $24 \mathrm{~h}$ in double distilled water and then fixed with a regular Osmium-fixation, using $2 \%$ Osmiumtetroxide, for $1.5 \mathrm{~h}$ (Griffith et al. 1972). After fixation, the sample was washed 3 times with distilled water. The post-fixation positive stain was carried out with a $2 \%$ aqueous uranyl-acetate solution (1 $\mathrm{h})$, and the washing procedure was repeated. Then the material was dehydrated in a series of ethanol washes $(30 \%, 50 \%, 70 \%, 90 \%, 100 \%)$, each for $15 \mathrm{~min}$. The material was transferred to propylene oxide for $15 \mathrm{~min}$. All above mentioned procedures were carried out at room temperature. The infiltration of the sample was done overnight in a 1:1 propylene oxide- Epon-resin-mix, at $4^{\circ} \mathrm{C}$. Then the sample was embedded in Epon-resin, with polymerization at $60^{\circ} \mathrm{C}$. Ultrathin-sectioning $(80-100 \mathrm{~nm})$ was performed with a diamant-knife, using a pyramytom. The slices were placed on a copper grid (400 squares) and counter stained with lead citrate, in a $\mathrm{CO}_{2}$ free environment. The ultrathinsections were examined with the EM Zeiss 910.

Protein preservation - Gas chromatography (GC) was used to separate and quantify the extent of aspartic acid racemisation. Three recent and ancient samples (each containing one individual) were washed for 3 min with $200 \mathrm{ml} 10 \%$ hydrochloric acid and then rinsed with double distilled water. The washing and rinsing steps were repeated twice. Then the material was crushed slightly in a liquid nitrogen cooled mill. The powder was dissolved in $200 \mathrm{ml} 6 \mathrm{~N}$ hydrochloric acid and placed on a rocker overnight at $4^{\circ} \mathrm{C}$. The samples were then evaporated to dryness and redissolved in double distilled water. Samples were desalted by TFF (tangential flow filtration), using the Pall Filtron Omega ${ }^{\text {TM }} 100$ VR (Kahn et al. 2000). To resolve the $\mathrm{D} / \mathrm{L}$ isomers by $\mathrm{GC}$, the Chirasil-Val capillary column (Alltech, USA), was used.

DNA extraction and sequencing - To ensure the authenticity and reproducibility of the results, the experiments were done independently with duplicate samples at 2 facilities, the Forschungszentrum Borstel (Zentrum für Medizin und Biowissenschaften) and the Insect Genetics Lab at Brigham Young University (BYU), Department of Zoology. All procedures were carried out under clean room conditions as described by Hofreiter et al. (2001). Fifteen fleas were combined in one sample, and 2 samples per animal mummy were analyzed. The samples were taken from three dog mummies (CHB 11671, CHB 11595, CHB 13177). For each sample the fleas were ground to powder in a $1.5 \mathrm{ml}$ Eppendorf-tube.

Two separate extractions of total DNA per dog mummy were done by phenol:chloroform extraction and the guanidinium thiocyanate method (Chomczynski \& Sacchi 1987). One control extraction per sample was done to detect for possible contamination of the extractionreagents by foreign DNA. Polymerase chain reaction (PCR) was used to amplify part of the nuclear $28 \mathrm{~S}$ rDNA gene (180 bp). PCR protocols were optimized with low-DNAconcentration templates, extracted from contemporary specimens. Internal 28S rDNA primers were designed from contemporary sequences [oldflea 1a(fwd): ACG CGA ATA AAT CCG TGA CA, oldflea 9b(rev): ACC TGA GAA ACC CGA AAG AT]. The amplification protocol was: $95^{\circ} \mathrm{C}$ for $12 \mathrm{~min}$ (initial denature), followed by 33 cycles at $94^{\circ} \mathrm{C}$ for $1 \mathrm{~min}$ (denature), $45^{\circ} \mathrm{C}$ for $1 \mathrm{~min}$ (annealing), $72^{\circ} \mathrm{C}$ for $1 \mathrm{~min}$ (extension), followed by $72^{\circ} \mathrm{C}$ for $5 \mathrm{~min}$ (final extend). The amplified segment includes 3 of 5 base pair positions where previously identified substitutions occur in contemporary Pulex sp. PCRs were carried out with the negative control, the archaeological extraction, one control contemporary sample and no-template samples (PCR negative control). The amplifications were performed in $50 \mu \mathrm{l}$ volumes of $37 \mu \mathrm{H} \mathrm{H}_{2} \mathrm{O}, 5 \mu \mathrm{l} 1.5 \mathrm{mM}$ dNTPs (mix), $5 \mu \mathrm{l} \mathrm{10X}$ buffer (100 mM Tris-HCl, ph 8.3; $500 \mathrm{mM} \mathrm{KCl;} 15 \mathrm{mM}$ $\mathrm{MgCl}_{2} ; 0.01 \%$ gelatin), $0.5 \mu \mathrm{l} 100 \mathrm{mM}$ of each primer, 0.125 $\mu \mathrm{l}$ Taq Gold Polymerase (Applied Biosystems) and $2 \mu \mathrm{l}$ template. To estimate the number of starting molecules in the template a competitive PCR was carried out (Zimmermann \& Mannhalter 1996). In competitive PCR, a known amount of a DNA fragment (competitor) is added to the sample. The competitor contains the sequences for the same primers used to amplify the target, so both templates will compete for the same primers. The ratio of the amount of the two amplified products reflects the ratio of the competitor (or internal standard) to the target DNA. Since the amount of the internal standard is known, the amount of the target sequence can be estimated. An internal standard template (competitor) was designed from contemporary DNA with composite primer pairs, which resulted in a fragment (28sSHORT) that was 50 bps shorter than the target strand. $1 \mu \mathrm{l}$ of a known dilution of $28 \mathrm{~s}$ SHORT was added to $1 \mu \mathrm{l}$ of the target template (archaeological sample). The competitive PCR products were separated on a $2 \%$ polyacrylamide gel and revealed an initial amount of starting template of less than 1000 copies. Therefore each PCR reaction was repeated 4 times. Addi- 
tional amplifications of the archaeological samples were performed with the insect $28 \mathrm{~S}$ rDNA primers $[4.8 \mathrm{a}(\mathrm{fwd})$ : ACC TAT TCT CAA ACT TTA AAT GG, 7b1 (rev) GAC TTC CCT TAC CTA CAT] (Whiting 2002), to test for an inverse relationship between amplicon length and amplification efficiency. The PCR products were purified with the Gene Clean ${ }^{\circledR}$ III Kit (BIO 101). One PCR product per sample was cloned into a pKYB1 Escherichia coli expression vector (high copy number vector, New England Bio Labs), using the EcoRI-restriction site for insertion. Plasmid DNA was prepared with the Quantum Prep® Plasmid Miniprep Kit (BIO-RAD). The inserts of ten plasmids from each sample were sequenced. DNA sequence analysis was carried out on an ABI 377 DNA sequencer using double-stranded plasmid templates and the BigDye terminator chemistry for preparation of the sequencing probes in accordance with protocols of the supplier (Applied Biosystems). A sequence database of contemporary Pulex sp. was created for the $28 \mathrm{~S}$ rDNA gene to compare the archaeological sequences against the contemporary data and confirm their authenticity. Sequences were aligned in Sequencher 3.1.1., adjustments were made by eye. A phylogenetic tree was generated under maximum parsimony criteria (Fig. 7), using the heuristic search option of PAUP 4.0 (Swofford 1998).

\section{RESULTS AND DISCUSSION}

According to current morphological keys, the archaeological specimens are assigned to $P$. simulans Baker, 1895 (Siphonaptera, Pulicidae). The genus Pulex is not clearly defined, it contains several species, of which the most common and important is P. irritans (human flea), and $P$. simulans, a closely related species. The morphological characters to distinguish the species solely rely on slight differences in the male genitalia (Smit 1958). All males of the archaeological specimens showed the characteristic elongated shape of the crochet. The dorsal aedeagal sclerite was broad and short (Smit 1958). No characteristics have yet been found to separate the females of the two species. Usually they are listed as one or the other according to their association with the male specimens. Numerous doubts exist whether to acknowledge two species $-P$. irritans and $P$. simulans or merge both into one species. Various records of cross mating on certain hosts have been reported (Tipton \& Mendez 1968, Tipton \& Machado-Allison 1972) and gene flow between populations or species is likely.

Insects are among the first organisms to invade a decaying body. Generally, it is difficult to assess the age of insect remain associated with an archaeological site. In this case, however, the parasitic life-style of the particular insect - the flea - indicates a true presence on the host before its death, as these parasites would never invade a dead or moribund animal. These fleas (Pulex sp.) are not sedentary and usually leave a dying host quickly in search of a more suitable one. According to Marshall (1981) fleas will abandon a host completely within $24 \mathrm{~h}$ after death. Therefore the evidence suggests that the animals were buried immediately or not long after death, as considerable numbers of fleas were still situated on the host.
Tissue preservation - Pristine tissue preservation does not necessarily lead to a retrieval of aDNA. However, the visualization of microscopic structures beyond regular light microscopy might reveal not only the state of cellular and intracellular preservation, but also the presence of invading bacteria or fungi, whose activity contribute to the eventual breakdown of DNA and biological matter in general.

Fig. 2 shows the thick laminated cuticle of a thoracic segment (tergite). It is comprised of fine chitin-protein microfibrills, with pore canals appearing as dark spots. Chitin is an insoluble linear polymer of $\mathrm{B}-1,4$-linked $\mathrm{N}$ acetylglucosaminic residues. It is one of the most resistant natural polymers, and only certain snails and fungi are known to generate chitinases, which will break it down. The individual polymer-chains are bound by hydroxide bonds and the protein arthropodin. The brown or dark color of the chitin of insects is due to sclerotin - another protein. The comparison to a contemporary sample (not shown here), demonstrated slightly wider spacing of the chitineous layers and a considerable loss of its coloring (Rothschild et al. 1986). This may be a result of a degradation of the necessary proteins, which were destroyed over time.

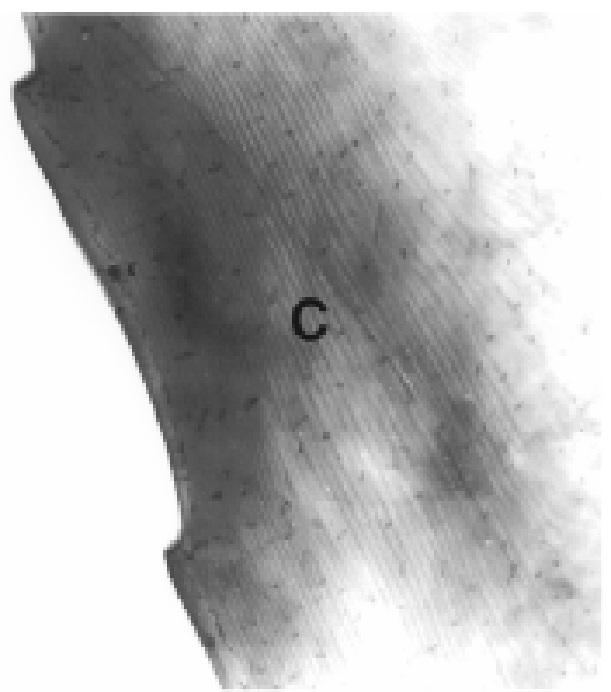

Fig. 2: electron micrograph of a section of the outer thoracic cuticle (C), Pulex sp., tergite, 10,000 X.

Tracheids and muscle tissue of rehydrated specimens are in a fairly good condition (Fig. 3). The taenidia of the inner tracheal wall are still clearly visible (Rothschild et al. 1986). The muscle tissue appears to be oblique. The clear areas within the muscle are remnants of the slightly distorted sarcoplasmic reticulum. Overall, the tissues seemed to be in an extraordinarily good state of preservation. However, in some samples, the infiltration and activity of bacterial cells was obvious (Fig. 4).

While the tracheids are clearly outlined, the surrounding tissue was replaced completely by bacterial cells. Bacteria are the first invaders after death, and they play a major role in decomposition. Naturally, no authentic insect DNA can be retrieved from these samples. 


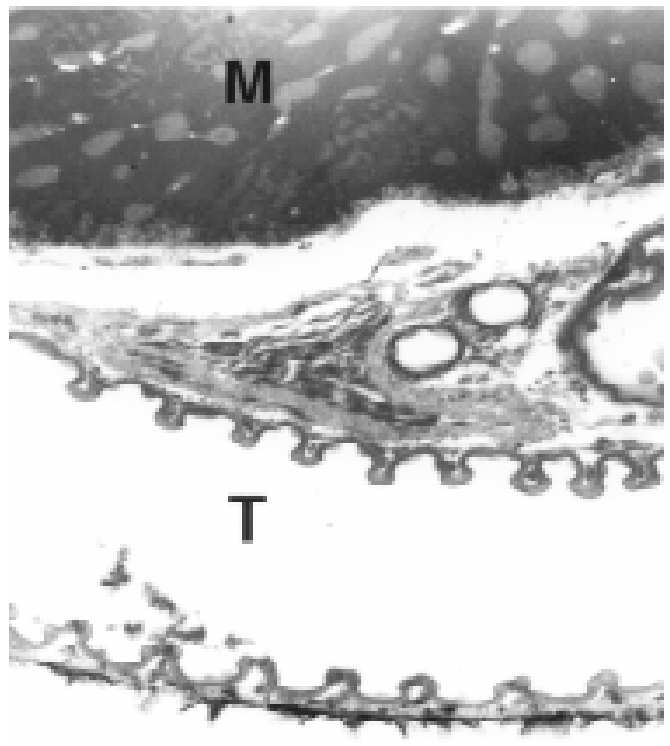

Fig. 3: electron micrograph of a section of the trachea (T) and a tubular stripped muscle (M), Pulex sp., thorax, 8,000 X.

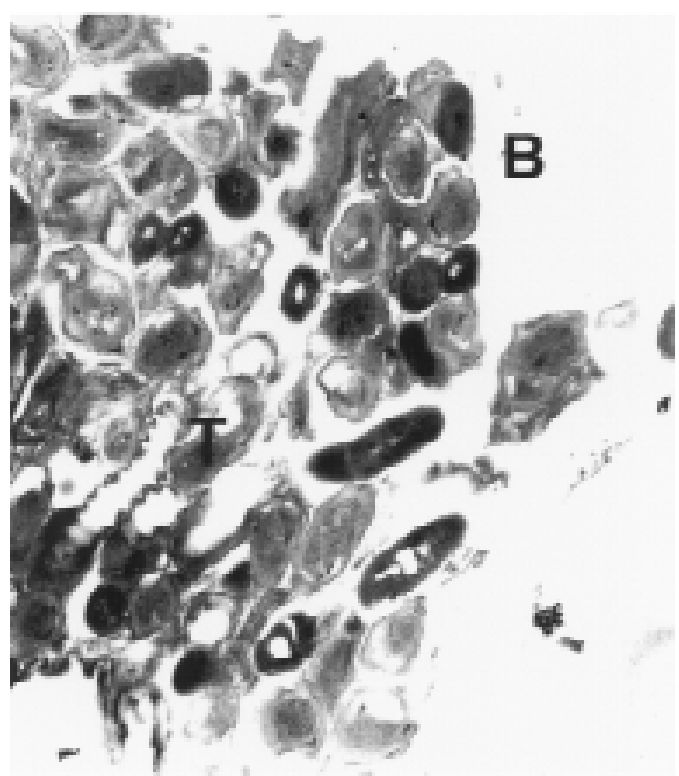

Fig. 4: electron micrograph of a section of tracheids (T) and bacterial cells (B), Pulex sp., thorax, 10,000 X.

Protein preservation - Proteins, as any other biological material, are also subjected to degradation, which starts immediately after death. Amino acids are the building units of proteins and can exist in two different optical isomers, the L-form (levorotatory) and the D-form (dextrorotatory). In living organisms they almost always exist in the L-form. Once taken out of the context of metabolism, the L-form and the D-form start to inter-convert, leading from an initial ratio of 0 to a final ratio of 1 (when $\mathrm{L}$ - and D-forms exist in equilibrium). This process is called amino acid racemization. Initially, the screening for the D/L ratio was mainly used for age assessments of geological and paleobiological material (Robins et al. 2001). Recently though, research- ers have found a connection between the $\mathrm{D} / \mathrm{L}$ ratio of aspartic acid and the preservation of aDNA (Poinar et al. 1996). Poinar et al. (1996) state that ratios above 0.08-0.10 usually yield no DNA. The contemporary samples all showed a ratio of 0.0 . Two archaeological samples (CHB 11671, CHB 13177) also resulted in a close approximation to a ratio of 0.0 . However, the results of the GC run showed, that only minuscule amounts of amino acids were present at all, suggesting the respective samples to be hollow remnants of chitin, which had been completely cleared of any tissue remains. Therefore the DNA-extractions were carried out with samples containing more than one flea specimen, so chances of including specimen with preserved DNA were higher.

Only one archaeological sample had a ratio of 0.09 (CHB 11595). This value lies in the above stated range. However, one has to be careful with the interpretation of the result, as this value does not necessarily mean a successful retrieval of DNA. It is only an indicator.

Extraction and sequencing - In the course of time DNA is exposed to various diagenetic factors (e.g. endogenous enzyme activity, oxidation, deamination, depurinisation). The efficiency and severity of those processes greatly vary with the environment and time. Often, very little or no DNA survives in ancient tissues (Greenwood et al. 1999). Environments of great aridity, like deserts, are known to provide extraordinarily favorable conditions for the preservation of organic material. However, recent research has shown that nearly no reproducible aDNA could be extracted from organic archaeological material of this origin (Poinar et al. 1996, Hofreiter et al. 2001). Heat, direct exposure to the sun and a constantly changing $\mathrm{pH}$ are especially unfavorable for the conservation of DNA. Thus, the area of the findings is situated in one of the less favorable spots, considering the preservation of biomolecules. The Moquegua Valley is among the most arid regions of the world, with temperatures reaching between $25^{\circ} \mathrm{C}$ and $38^{\circ} \mathrm{C}$ throughout the year. However, the mummification event in this case is very recent, the $\mathrm{pH}$ of the soil stays at a constant neutral condition and the burial shafts were dug deep into the sand (ca. 2 $\mathrm{m})$, preventing sunlight from reaching the mummies.

Another threatening factor in aDNA work is contamination by contemporary DNA, therefore great precaution has to be taken with the collection and processing of the material. Because of the abundance of insect life, insect DNA is quite prevalent in the environment and may contaminate samples. Therefore flea DNA sequences were generated with recent specimens of the genus Pulex. Thus, a comparative database was provided, and the archaeological sequences could be confirmed to be genuine flea DNA.

The extractions from mummies CHB 11595 and CHB 13177 were positive for DNA in both samples, independent of the applied extraction method. All other samples yielded no DNA. Furthermore, the results were reproduced independently in the two labs. The guanidinium thiocyanate method seemed to yield more DNA template. All mock extractions and negative controls remained negative throughout the experiments. The $28 \mathrm{~S}$ rDNA-gene was chosen for amplification as it is tandemly repeated and 
exists in multiple copies, increasing the possibility of amplification. However, the quantification by competitive PCR revealed a very low number of DNA molecules per sample. This can lead to a series of misincorporation of bases into the sequence during PCR, especially when the template is damaged. To lower the risk of getting a repeated error through misincorporations, each PCR was repeated 4 times. Independently, some templates were subjected to cloning prior to sequencing. Misincorporations would then be detectable in the resulting sequences of the clones. All PCRs generated the same sequence, therefore no misincorporations of base pairs could be detected. All clones produced the same sequence of 180 base pairs (Fig. 5).

No sequences were generated with the 28S rDNA insect primers that covered more than 200 base pairs.

The prehispanic sequence was identical to the sequence of contemporary samples from Peru. This is not surprising, as $28 \mathrm{~S} \mathrm{rDNA}$ is known to be a very conserved gene at the intra- and interspecific level. However, in comparison to contemporary sequences from North American material three positions were found, where substitutions had occurred (Table). This could either be explained by true intraspecific (P. simulans ancient South America versus $P$. simulans North America) and/or interspecific differences (P. simulans versus P. irritans) in this gene or attributed to the fact that $28 \mathrm{~S}$ rDNA is a multi-copy gene, where base pair changes may not be fully concerted. More data have to be generated to substantiate either hypothesis.

To test if the sequences make phylogenetic sense, a tree was generated including the taxa $P$. irritans, $P$. simulans, Xenopsylla cheopis, Parapulex and Ctenocephalides canis (all Pulicidae) (Fig. 6). The tree was rooted to Tiamastus cavicola (Rhopalopsyllidae).

Further research - The availability of considerable sample sizes of Pulex sp. from ancient populations from Peru, as well as contemporary samples from throughout the world, provide excellent opportunities for a closely linked study of population genetics and phylogeographic aspects of these species from a unique historical standpoint. Morphological and molecular studies with the archaeological specimen could help resolving the currently confusing taxonomy.
The classic hypothesis regarding the distribution of the genus is that of dispersal from South America, through North America, crossing the Bering Strait, and finally reaching Europe and Asia (Hopla 1980, Buckland \& Sadler 1989). The findings of Pulex sp. on the animal mummies in Peru imply the presence of this genus in South America prior to the Spanish Conquista and strengthen the hypothesis of its origin in the New World. No knowledge exists about the time frame of the dispersal event. The archaeological specimen provide an ancestral population within a 1,000 year time frame, and data derived from that population can help to resolve the possible time of population divergence (Edwards \& Beerli 2000). Currently, further studies with nuclear and mitochondrial genes are under way. Preliminary results point towards an existing metapopulation of Pulex sp., with $P$. simulans and $P$. irritans forming several subpopulations, in association to their hosts.

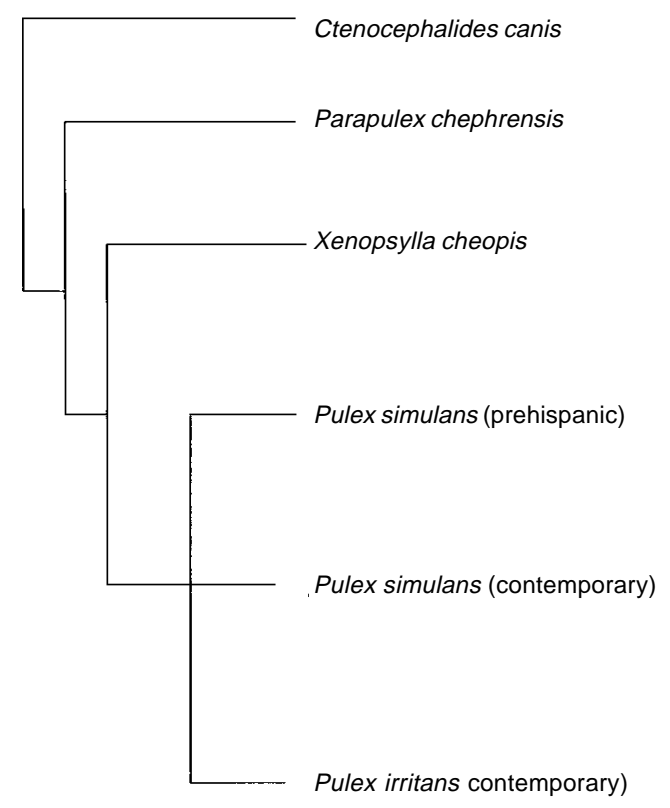

Fig. 6: strict consensus tree of $28 \mathrm{~S}$ rDNA-data, maximum parsimony.

\section{GGCTACCGCCGCGGTCGTAGATTGACACCCAACGGGTCGCGACGTCCTACTGG AAGAGAAGTGCATGCTGCTGTCGTCACCGTACGCAGAAGTAGACGGCGTATCG CGAGACGAATCCCGGTCAATCGCACGACGACAAAAGGACAGCAACGATAACA CTGAATCTCTCCGTTCGATCTT}

Fig. 5: 180 base pair long sequence of $28 \mathrm{~S}$ rDNA from an archeological specimen of Pulex sp.

TABLE

Sequence alignment of Pulex sp. (Sequencher 3.1.1.) from different geographical regions, indicating the position of base pair changes in the 28S rDNA

P. simulans (ancient, South America)

P. simulans (North America)

P. irritans (North America)
TAGATTGACAC:::::GAAGTAGACGG::::CAGCAACG

TAGATGGACAC:::::GAAGTCGACGG::::CAGCAACG

TAGATCGACAC:::::GAAGTCGACGG::::CAGCTACG 
Members of the genus Pulex have long been discussed as vectors for certain diseases, among which are the plague bacterium Yersinia pestis and the agent for murine typhus (Rickettsia mooseri). Most of the time the vectorfunction has been assigned only to $P$. irritans, neglecting the role of the more widespread and abundant $P$. simulans. Therefore this problem is closely linked to the former, as this confusion has stemmed from the poorly understood taxonomy of this group. On the other hand, the roles of both "species" in the ecology of those diseases have never been properly evaluated. The abundance of both "species" in rural areas of Peru in humans and domestic animals (Cavia aperea f. porcellus) is of considerable importance (Hopla 1980, Dittmar 2000). Ramoz Dias (1938) reported a case of plague transmission by $P$. irritans from an epizootic of rats to domestic guinea pigs to humans in Lambayeque, Peru. Plague is endemic in Peru, in the sense that it is restricted to certain localities. Y. pestis is believed to have evolved from the relatively innocuous enteric pathogen Y. pseudotuberculosis between 1,500 and 20,000 years ago (Parkhill et al. 2001). It has never been estimated with certainty when the plague bacterium was established in the Americas and according to this estimated speciation event, chances are that it existed in South America prior to the Spanish Conquista. The availability of the prehispanic vectors provide the potential to assess this problem.

\section{REFERENCES}

Araujo A, Ferreira LF, Guidon N, Serra Freire NM, Reinhard K, Dittama K 2000. Ten thousand years of head lice infection. Parasitol Today 16: 269.

Bryant VM 1974: The role of coprolite analysis in archaeology. Bull Texas Archaeol Soc 45: 1-28.

Buckland PC, Sadler JP 1989. A biogeography of the human flea, Pulex irritans L. (Siphonaptera: Pulicidae). J Biogeography 16: 115-120.

Chomczynski P, Sacchi N 1987. Method of RNA isolation by acid guanidine thiocyanate: phenol: chloroform extraction. Anal Biochem 162: 156- 159.

Dittmar K 2001. Untersuchungen zum Vorkommen von Ektoparasiten bei domestizierten und wildlebenden Meerschweinchen (Cavia spp.) sowie an präinkaischen Meerschweinchenmumien in Peru, Südamerika, Thesis, University of Leipzig, Leipzig, 160 pp.

Edwards SV, Beerli P 2000. Perspective: gene divergence, population divergence, and the variance in coalescence time in phylogeographic studies. Evolution 54: 1839-1854.

Ewing HE 1924. Lice from human mummies. Science 60: 389390.

Girling MA 1978. The application of fossil insect studies to the Somerset levels. In T Brothwell, Research Problems in Zooarchaeology, Clutton-Brock-Publishers, London, p. 8589.

Gothe R, Schöl H 1992. Hirschlausfliegen (Diptera, Hippoboscidae: Lipoptena cervi) in den Beifunden der Leiche vom Hauslabjoch. In F Höpfel, W Platzer, K Spindler (eds), Der Mann im Eis. Band 1, Bericht über das Internationale Symposium in Innsbruck, Wien, p. 299-306.

Greenwood AD, Capelli C, Possnert G, Paabo S 1999. Nuclear DNA sequencesfrom late Pleistocene Megafauna. Mol Biol Evol 16: 1466-1473.

Griffith OH, Lesch GH, Rempfer GF, Birrell GB, Burke CA,
Schlosser DW, Mallon M H, Lee GB, Stafford RG, Jost PC, Marriott TB 1972. Photoelectron microscopy: a new approach to mapping organic and biological surfaces. Proc Natl Acad Sci USA 69: 561-565.

Hopla CE 1980. A study of the host associations and zoogeography of Pulex. In R Traub, H Starcke (eds), Fleas, A.A. Balkema, Rotterdam, p. 185- 207.

Hofreiter M, Serre D, Poinar HN, Kuch M, Pääbo S 2001. Ancient DNA. Nature 2: 353-359.

Kahn DW, Butler MD, Cohen DL, Gordon M, Kahn JW, Winkler ME 2000. Purification of plasmid DNA by tangential flow filtration. Biotechnol Bioeng 69: 101-106.

Kenward HK 1978a. The value of insect remains as evidence of ecological conditions on archaeological sites. In T Brothwell, Research Problems in Zooarchaeology, Clutton-Brock-Publishers, London, p. 25-38.

Kenward HK 1978b. The analysis of archaeological insect assemblages: A new approach. Council for British Archaeology. The Archaeology of York 19: 1-67.

Lee T, Chou H 2000. Isolation and identification of seven microcystins from a cultured $M$. TN-2 strain of Microcystis aeruginosa. Bot Bull Acad Sin 41: 197- 202.

Marshall AG 1981. The Ecology of Ectoparasitic Insects, Academic Press Inc., London, 459 pp.

Panagiotakopulu E, Buckland PC, Day PM 1995. Natural insecticides and insect repellents in Antiquity: A review of the evidence. J Arch Sci 22: 705-710.

Panagiotakopulu E, Buckland PC, Day PM, Doumas C, Sarpaki A, Skidmore P 1997. A lepidopterous cocoon from Thera and evidence of silk in the Aegean Bronze Age. Antiquity 71: 420-429.

Panagiotakopulu E 1999. An examination of biological materials from coprolites from XVIII Dynasty Amarna, Egypt. $J$ Arch Sci 26: 547-551.

Parkhill J, Wren BW, Thomson NR 2001. Genome sequence of Yersinia pestis, the causative agent of plague. Nature 413: 523-527.

Poinar HN, Höss M, Bada JL, Pääbo S 1996. Amino acid racemisation and the preservation of ancient DNA. Science 272: 864-866.

Ramos Diaz A 1938. Epidemiologia de la peste bubonica en la sierra del departamento de Lambayeque. Bol Ofic Sanit Panam 17: 776-780.

Robins J, Jones M, Matisoo-Smith E 2001. Amino Acid Racemication Dating in New Zealand: An Overview, Auckland University Private Bag 92019, Auckland, p. 145.

Rothschild M, Schlein Y, Susumo I 1986. A Colour Atlas of Insect Tissues. Via the Flea, Wolfe Publishing Ltd., London, $180 \mathrm{pp}$.

Smit FGAM 1958. A preliminary note on the occurrence of Pulex irritans L. and Pulex simulans Baker in North America. J Parasitol 44: 523-526.

Swofford DL 1998. PAUP* 4.0 - Phylogenetic Analysis Using Parsimony (*and Other Methods). Sinauer Assoc., Sunderland, p. 1-187.

Tipton VJ, Machado-Allison, CE 1972. Fleas of Venezuela. Brigham Young Univ Sci Bull Biol Ser 17, 115 pp.

Tipton VJ, Mendez E 1968. New species of fleas (Siphonaptera) from Cerro Potosi, Mexico, with notes on ecology and host parasite relationships. Pacific Insects 10: 177-214.

Whiting M F 2002. Mecoptera is paraphyletic: multiple genes and phylogeny of Mecoptera and Siphonaptera. Zool Scripta 31: 93-105.

Zimmermann K, Mannhalter JW 1996. Technical aspects of quantitative competitive PCR. BioTechniques 21: 268-279. 